\title{
Exploring the social-ecological systems discourse 20 years later
} Johan Colding ${ }^{1,2,3}$ and Stephan Barthel ${ }^{1,3}$

\begin{abstract}
This paper explores the 20-year evolution of the social-ecological systems framework (SESs). Although a first definition of SES dates back to 1988, Berkes and Folke more thoroughly used the concept in 1998 to analyze resilience in local resource management systems. Since then studies of interlinked human and natural systems have emerged as a field on its own right, promoting interdisciplinary dialogue and collaboration in a wide set of fields and practices. As the SES concept celebrates its 20-year existence we decided to make an overview of how authors use the concept in relation to research that deals with social and ecological linkages. Hence, we conducted a review of the SES concept using the Scopus database, analyzing a random set of journal articles on social-ecological systems $(\mathrm{n}=$ 50) regarding definitions of SES, authors' main sources of inspiration in using the concept, as well as document type, subject area, and other relevant information. Although there is a steady increase of SES publications, we found that $61 \%$ of the papers analyzed did not even provide a definition of the term social-ecological system(s), a shortcoming that makes case comparisons difficult and reduces the usefulness of the concept. We also found three common SES frameworks that authors seem to be most commonly inspired by, referred to here as the original, the robustness, and multitier frameworks, respectively. The first can be characterized as a descriptive framework, the latter two more as diagnostic frameworks, useful for modeling. Although it would be a bit presumptuous of us to come up with a more thorough definition of the SES concept in this paper, we urge SES scholars to be more meticulous in making explicit what they mean by a social-ecological system when conducting SES research.
\end{abstract}

Key Words: multitier framework; original SES framework; robustness framework; SES modeling; social-ecological systems

\section{INTRODUCTION}

Almost five decades have passed since the notion of a socialecological system (SES) first was coined (Ratzlaff 1970). However, it was not until 20 years ago that the concept was turned into a framework for the study of intertwined human and natural systems (Berkes and Folke 1998). Since then the SES concept has been widely used in both the environmental and social sciences, as well as in economics, and in such diverse knowledge fields as medicine, psychology, and the arts and humanities.

Although Berkes and Folke were unaware of it at the time, the first definition of a social-ecological system was actually made by the Russian microbiologist B. L. Cherkasskii, who defined a social-ecological system as a system:

\section{... consisting of two interacting subsystems: the biological (epidemiological ecosystem) and the social (social and economic conditions of life of the society) subsystems where the biological subsystem plays the role of the governed object and the social acts as the internal regulator of these interactions (Cherkasskii 1988:321).}

It took 10 more years until Berkes and Folke (1998) developed the concept as an analytical framework for the study of the linkages between ecosystems and institutions (Fig. 1). More specifically, they used it to broaden understanding of how resilience is built into local resource management systems, or in the words of Folke and Berkes (1998:4), "[t]he challenge is to find ways to match the dynamics of institutions with the dynamics of ecosystems for mutual social-ecological resilience and improved performance."

In fact, the concept was originally used in a transdisciplinary research project at the Beijer Institute of Ecological Economics that started in early 1998. The purpose behind this project, referred to as "Dynamics of Ecosystem-Institution Linkages for Building Resilience," was to analyze critical linkages in socialecological systems, and to generate insights on how to interpret, respond to, and manage feedbacks from complex adaptive systems. The long-term objective was to improve resource management.

Fig. 1. A conceptual framework for the analysis of linked social-ecological systems. Ecological knowledge and understanding is a critical link between complex and dynamic ecosystems, adaptive management practices, and institutions. Source: Based on and modified from Folke and Berkes (1998).

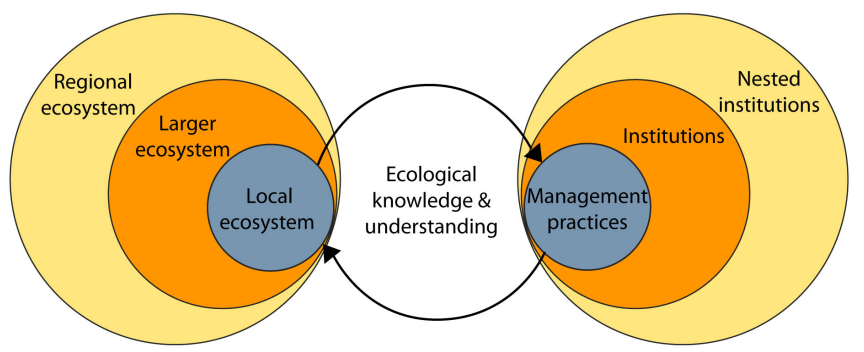

Berkes and Folke used the term social-ecological, rather than socio-ecological, because "social-ecological emphasizes that the two subsystems are equally important, whereas socio- is a modifier, implying a less than equal status of the social subsystem" (Berkes 2017:3). Because it is 20 years since the study of interlinked social-ecological systems first emerged, we take the opportunity to examine and assess the evolution of the SES discourse in closer detail. By the term discourse we mean a body

${ }^{1}$ Department of Building, Energy and Environmental Engineering, University of Gävle, Sweden, ${ }^{2}$ The Beijer Institute of Ecological Economics, The Royal Swedish Academy of Sciences, Sweden, ${ }^{3}$ Stockholm Resilience Centre, Stockholm University, Sweden 
Fig. 2. Publications related to social-ecological systems, covering the years 1998-2016. Source: Based on data in the Scopus database, accessed 20 August 2017.

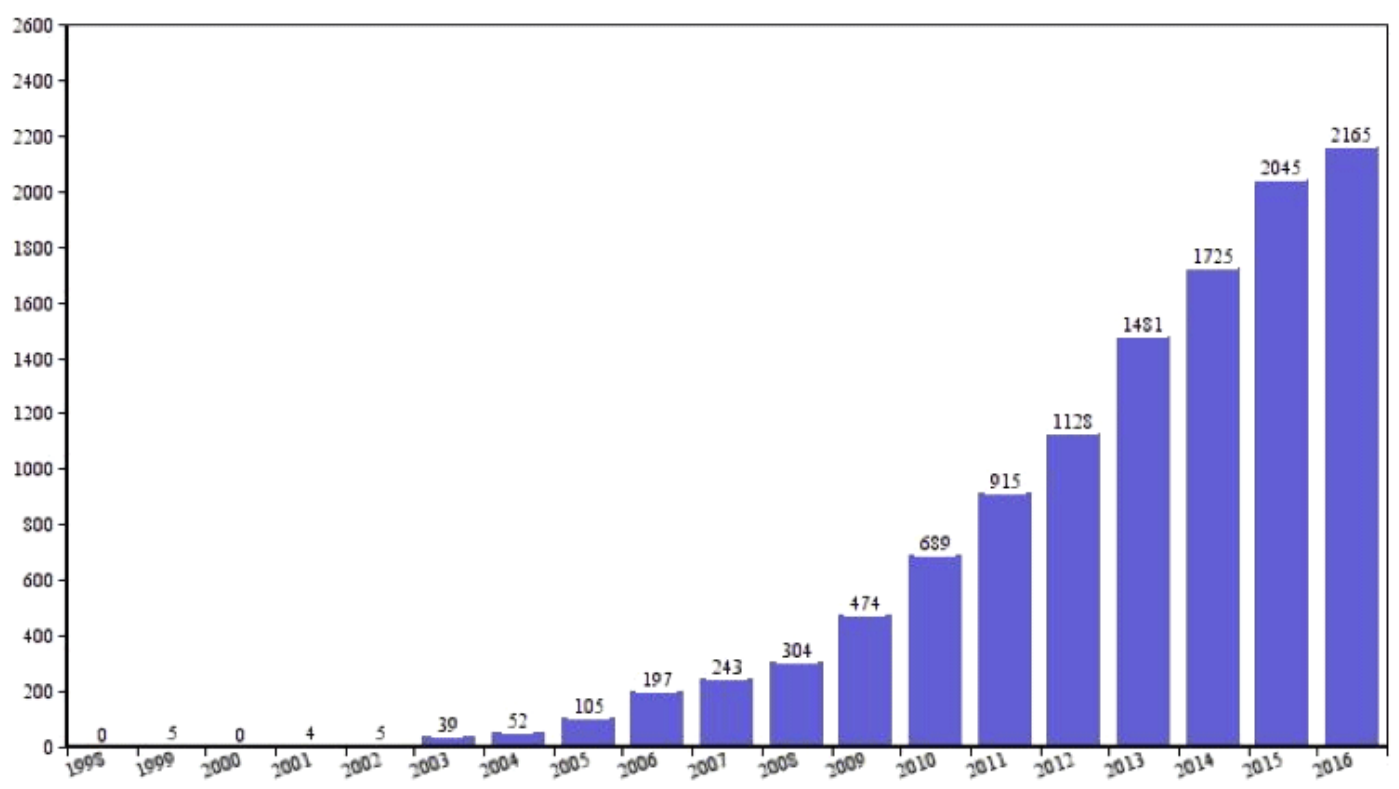

of text meant to communicate specific data, information, and knowledge. Hence, we assessed the scientific literature to analyze how the SES concept has evolved over time since the concept's first introduction in the fields of systems ecology, ecological economics, and natural resource management. We also wanted to see how scholars define the SES concept, the major SES frameworks used by scholars conducting research on socialecological systems, as well as target other inquiries.

\section{METHODS}

An assessment of the SES-concept was conducted in the peerreviewed scientific literature, consisting of two phases. Being aware of the multidisciplinary nature of the topic and the huge number of publications, the first phase was geared at retrieving a broad overview and scope of the SES subject field. Hence, we performed an advanced literature search query on the Scopus database, downloaded from the Stockholm University Library on 20 August 2017. The words "social-ecological systems" was entered in all fields in order to retrieve articles and other documents dealing with SES, such as proceeding papers, books, book chapters, or doctoral theses, and searched in the options "all text," "article title," "abstract," and "keywords." From this we retrieved 12,990 documents dealing with social-ecological systems. Results were analyzed regarding publication date, document type, subject area, and author name.

Because the Scopus database does not distinguish between the term social-ecological systems cited in the reference lists and the main text of publications, we decided to further study only those documents encompassing the term social-ecological systems in the title, abstract, and/or as a keyword. Hence, the second phase consisted of retrieving all journal articles on SES, which we then analyzed in more detail. The word social-ecological system was entered in all fields and searched in the options title, abstract, keywords, and limited to journal articles. This resulted in a sample of 1598 publications. Fifty of these were selected for a more detailed analysis. Articles were randomly selected using a random number generator (i.e., http://gallerit.se/slumptal/). Out of the 50 articles, one was dropped because the main text was in Chinese. This, second search query, was also downloaded on 20 August 2017 from the Stockholm University Library, using the Scopus database. The 49 remaining articles used for analysis were assessed for the following: (1) number and proportion of articles that define SES; (2) definitions of SES employed; and (3) main sources of inspiration. Each paper selected for review was carefully read and analyzed by both authors regarding the three analytical components. We made a qualitative assessment by analyzing the text and sources of inspiration. These sources were determined by the theoretical framework that authors referred to in their articles. Both authors have been a critical part of the development of the field and can therefore be considered to hold somewhat of an insider perspective on the evolution of the SES discourse.

\section{RESULTS}

Our Scopus review showed that there exist some 12,990 publications of SES since 1970 in a variety of scientific outlets. These fall into the following categories: articles (9583); book chapters (1150); reviews (1105); conference papers (467); books (332); editorials (192); articles in press (48); notes (47); short surveys (38); letters (22); errata (4); and conference reviews (2).

In terms of subject area, studies on SES derive from the environmental sciences (7997); social sciences (5315); agricultural and biological sciences (3602); earth and planetary sciences (1422); economics, econometrics, and finance (1100); business, management, and accounting (871); engineering (763); medicine (674); energy (523); arts and humanities (427); and computer science (383), as well as a range of other areas. Ever since the SES 
concept was developed in 1998 by Berkes and Folke, there has been a yearly steady increase of publications in this field (Fig. 2).

The authors that top the list of SES publications are Carl Folke and Fikret Berkes with 113 and 84 publications, respectively, followed by B. Martín-López (66); M. A. Janssen (65); J. E. Cinner (61); and E. Ostrom (60). Among the total number of journal publications $(\mathrm{T}=1598)$, the top five journals that most frequently have dealt with SES at the date of our assessment included Ecology and Society (394 articles); Global Environmental Change (57); Marine Policy (49); International Journal of the Commons (38); and Environmental Science and Policy (37).

The review of the 49 journal publications used for more detailed analysis showed that 30 of these did not contain a definition of SES, representing $61 \%$ (see Table 1 ). As evident from our analysis, there exist quite a number of different definitions of what a socialecological system is. These definitions span from more rudimentary ones to more qualified definitions, as exemplified in the following. A social-ecological system can be defined as the following:

- "a system of people and nature" (Thomas et al. 2012:69).

- a system "where social and ecological systems are mutually dependent" (Fidel et al. 2014:48).

- "interdependent and linked systems of people and nature that are nested across scales" (Bouamrane 2016).

- "a system that includes societal (human) and ecological (biophysical) subsystems in mutual interactions" (Harrington et al. 2010:2773).

- a system that "includes the entities of common-pool resource, resource users, public infrastructure, infrastructure providers, institutional rules, external environment and the links between these entities" (Özerol 2013:73).

- "complex adaptive systems with key characteristics such as: (1) integrated biogeophysical and socio-cultural processes, (2) self-organization, (3) nonlinear and unpredictable dynamics, (4) feedback between social and ecological processes, (5) changing behavior in space (spatial thresholds) and time (time thresholds), (6) legacy behavioral effects with outcomes at very different time scales, (7) emergent properties, and (8) the impossibility to extrapolate the information from one SES to another" (Delgado-Serrano et al. 2015).

Among the journal publications analyzed we found three major sources of inspiration: Berkes and Folke (1998) and Berkes et al. (2003) that were cited 19 times by authors; Ostrom $(2007,2009)$, cited 10 times, and Anderies et al. (2004), cited 4 times (Table 1).

\section{DISCUSSION}

It is interesting to see how the concept of SES has been able to penetrate so many disciplines. Since the time of its first conceptualization the number of SES publications has steadily increased each year (Fig. 2).

As our assessment suggests, the two most common subject areas dealing with SES are the environmental sciences and the social sciences. However, the SES concept has also penetrated such a diverse set of subject areas as economics, engineering, medicine, computer science, and the arts and humanities.
It is not surprising that Carl Folke and Fikret Berkes are the two scholars most frequently cited in relation to the SES concept because both can be viewed as the originators of the SES research. Among the journal publications analyzed we found three major sources of inspiration: Berkes and Folke (e.g. Berkes and Folke1998, Berkes et al. 2003); Ostrom (2007, 2009); and Anderies et al. (2004; Table 1). Each of these SES frameworks are often used in parallel by scholars, and are here referred to as the original, the robustness, and multitier frameworks, respectively.

\section{The original SES framework}

When Carl Folke and Fikret Berkes developed the first SES framework it was primarily used for addressing the questions, what confers institutional resilience, and how can institutional resilience be combined with ecological resilience for mutual benefit (Folke and Berkes 1998). In particular, the focus was on local management systems that had not been dominated by conventional resource management and mechanistic, linear thinking and practice, and those that had maintained practices for the building of resilience in local settings (Folke and Berkes 1998). Most of the cases dealt with were local common property systems.

As the analytical framework used by Berkes and Folke indicates (Fig. 1) the idea was to provide an analytical structure for studying these local resource management systems. As the figure displays, on the left-hand side is the natural system, which may consist of nested ecosystems, e.g., a regional ecosystem containing the drainage basin of a river, which in turn consists of a number of watershed ecosystems and so on. On the right-hand side, is a set of management practices in use. These practices are embedded in institutions, and the institutions themselves may be a nested set.

The critical distinction made here was that the linkage between the ecosystem and management practice was provided by ecological knowledge and understanding of the resource users' local ecosystem, or the resource base on which they depended. This knowledge linkage was deemed critical because without ecological knowledge and understanding of the dynamics of the resource base the likelihood for sustainable use was assumed to be severely reduced (Folke and Berkes 1998). Such knowledge and understanding was in turn believed to be reflected in and built into different management practices that in turn were framed by local institutions, primarily of an informal nature (Colding and Folke 2001).

Interestingly, the basic idea behind this approach of analyzing socially and ecologically linked resource management systems was similar to the one used by Ostrom in her field studies of the practices that could be observed in the governance of commonpool irrigation systems (Ostrom 1990, 2010). This approach is also what anthropologists refer to as participant observation (Keesing 1981).

As also sketched in Figure 1, the social-ecological system is an open system, with a number of influences impinging on it, such as population growth, technological change, effects of capital markets, and trade. Political change and pressures of globalization were also considered major influences on the system.

The SES framework was later used in the context of understanding adaptability of social-ecological systems, to meet change and novel challenges and navigate ecosystem dynamics 
Table 1. Fifty randomly selected publications for analysis of articles $(\mathrm{T}=1598)$ dealing with social-ecological systems $(\mathrm{SESs})$ from 1998 to 2017, based on abstract (Abstr.), keyword (KW), title, and limited to articles. Information retrieved on 20 August 2017 from the Scopus database. Source of inspiration denotes to key document(s) as referred to by author in relation to SESs.

\begin{tabular}{|c|c|c|c|}
\hline Source & Occurr-ence & $\begin{array}{l}\text { Definition of } \\
\quad \text { SES }\end{array}$ & $\begin{array}{l}\text { Major source of } \\
\text { inspiration }\end{array}$ \\
\hline $\begin{array}{l}\text { K. Y. Kaneshiro, P. Chinn, K. N. Duin, A. P. Hood, K. Maly, and B. A. Wilcox. } 2005 . \\
\text { Hawai'i's mountain-to-sea ecosystems: social-ecological microcosms for sustainability } \\
\text { science and practice. EcoHealth 2:349-360. http://dx.doi.org/10.1007/s10393-005-8779- } \\
\text { z }\end{array}$ & Abstr. & No & Berkes and Folke 1998 \\
\hline $\begin{array}{l}\text { MacMynowski, D. P. 2007. Across space and time: social responses to large-scale } \\
\text { biophysical systems. Environmental Management 39:831-842. http://dx.doi.org/10.1007/ } \\
\text { s00267-006-0082-4 }\end{array}$ & KW & No & Undetermined \\
\hline $\begin{array}{l}\text { Rescia, A. J., A. Pons, I. Lomba, C. Esteban, and J. W. Dover. 2008. Reformulating the } \\
\text { social-ecological system in a cultural rural mountain landscape in the Picos de Europa } \\
\text { region (northern Spain). Landscape and Urban Planning 88:23-33. http://dx.doi. } \\
\text { org/10.1016/i.landurbplan.2008.08.001 }\end{array}$ & Title & No & Berkes and Folke 1998 \\
\hline $\begin{array}{l}\text { Harrington, R., C. Anton, T. P. Dawson, F. de Bello, C. K. Feld, J. R. Haslett, T. } \\
\text { Kluvánkova-Oravská, A. Kontogianni, S. Lavorel, G. W. Luck, et al. 2010. Ecosystem } \\
\text { services and biodiversity conservation: concepts and a glossary. Biodiversity and } \\
\text { Conservation 19(10):2773-2790. http://dx.doi.org/10.1007/s10531-010-9834-9 }\end{array}$ & KW & Yes & Berkes and Folke 1998 \\
\hline $\begin{array}{l}\text { Rounsevell, M. D. A., T. P. Dawson, and P. A. Harrison. 2010. A conceptual } \\
\text { framework to assess the effects of environmental change on ecosystem services. } \\
\text { Biodiversity and Conservation 19:2823-2842. http://dx.doi.org/10.1007/ } \\
\text { s10531-010-9838-5 }\end{array}$ & KW & Yes & Berkes and Folke 1998 \\
\hline $\begin{array}{l}\text { Sahlberg, P., and D. Oldroyd. 2010. Pedagogy for economic competitiveness and } \\
\text { sustainable development. European Journal of Education } 45(2): 280-299 . \text { http://dx.doi. } \\
\text { org/10.1111/j.1465-3435.2010.01429.x }\end{array}$ & Main text & No & Undetermined \\
\hline $\begin{array}{l}\text { Turner, M. G. 2010. Disturbance and landscape dynamics in a changing world. } \\
\text { Ecology 91(10):2833-2849. http://dx.doi.org/10.1890/10-0097.1 }\end{array}$ & Abstr. & No & Undetermined \\
\hline $\begin{array}{l}\text { Auclair, L., P. Baudot, D. Genin, B. Romagny, and R. Simenel. 2011. Patrimony for } \\
\text { resilience: evidence from the forest Agdal in the Moroccan High Atlas Mountains. } \\
\text { Ecology and Society 16(4):24. http://dx.doi.org/10.5751/ES-04429-160424 }\end{array}$ & Abstr., KW & No & Berkes et al. 2003 \\
\hline $\begin{array}{l}\text { Janssen, M. A., F. Bousquet, and E. Ostrom. 2011. A multimethod approach to study } \\
\text { the governance of social-ecological systems. Natures Sciences Sociétés 19:382-394. }\end{array}$ & Title & No & Ostrom 2007 \\
\hline $\begin{array}{l}\text { Thomas, C. R., I. J. Gordon, S. Wooldridge, and P. Marshall. 2012. Balancing the } \\
\text { tradeoffs between ecological and economic risks for the Great Barrier Reef: a } \\
\text { pragmatic conceptual framework. Human and Ecological Risk Assessment 18(1):69-91. } \\
\text { http://dx.doi.org/10.1080/10807039.2012.631470 }\end{array}$ & Abstr. & Yes & Carpenter 2008 \\
\hline $\begin{array}{l}\text { Anderson, P. M. L., and P. J. O'Farrell. 2012. An ecological view of the history of the } \\
\text { City of Cape Town. Ecology and Society 17(3):28. http://dx.doi.org/10.5751/ } \\
\text { ES-04970-170328 }\end{array}$ & Abst. & No & $\begin{array}{l}\text { Holling and Gunderson 2002, Walker et } \\
\text { al. } 2006\end{array}$ \\
\hline $\begin{array}{l}\text { Barron, E. S., and M. R. Emery. 2012. Implications of variation in social-ecological } \\
\text { systems for the development of U.S. fungal management policy. Society \& Natural } \\
\text { Resources 25(10):996-1011. http://dx.doi.org/10.1080/08941920.2011.650348 }\end{array}$ & Title, Abstr. & No & Undetermined \\
\hline $\begin{array}{l}\text { Özerol, G. 2013. Institutions of farmer participation and environmental sustainability: } \\
\text { a multi-level analysis from irrigation management in Harran Plain, Turkey. } \\
\text { International Journal of the Commons 7(1):73-91. http://dx.doi.org/10.18352/ijc. } 368\end{array}$ & Abstr. & No & Anderies et al. 2004 \\
\hline $\begin{array}{l}\text { Cranford, P. J., P. Kamermans, G. Krause, J. Mazurié, B. H. Buck, P. Dolmer, D. } \\
\text { Fraser, K. Van Nieuwenhove, F. X. O'Beirn, A. Sanchez-Mata, G. G. Thorarinsdóttir, } \\
\text { and Ø. Strand. 2012. An ecosystem-based approach and management framework for } \\
\text { the integrated evaluation of bivalve aquaculture impacts. Aquaculture Environment } \\
\text { Interactions 2:193-213. http://dx.doi.org/10.3354/aei00040 }\end{array}$ & KW & Yes & Janssen and Ostrom 2006 \\
\hline $\begin{array}{l}\text { Holmes, M. C. C., and W. (S. P.) Jampijinpa. 2013. Law for country: the structure of } \\
\text { Warlpiri ecological knowledge and its application to natural resource management and } \\
\text { ecosystem stewardship. Ecology and Society } 18(3): 19 \text {. http://dx.doi.org/10.5751/ } \\
\text { ES-05537-180319 }\end{array}$ & KW & No & Berkes et al. 2003 \\
\hline $\begin{array}{l}\text { Epstein, G., J. M. Vogt, S. K. Mincey, M. Cox, and B. Fischer. 2013. Missing ecology: } \\
\text { integrating ecological perspectives with the social-ecological system framework. } \\
\text { International Journal of the Commons } 7: 432-453 \text {. http://dx.doi.org/10.18352/ijc.371 }\end{array}$ & Title, KW & No. & Ostrom 2007, 2009 \\
\hline $\begin{array}{l}\text { Villasante, S., G. Macho, M. Antelo, D. Rodríguez-González, and M. J. Kaiser. } 2013 . \\
\text { Resilience and challenges of marine social-ecological systems under complex and } \\
\text { interconnected drivers. Ambio 42(8):905-909. http://dx.doi.org/10.1007/ } \\
\text { s13280-013-0450-2 }\end{array}$ & $\begin{array}{l}\text { Title, Abstr., } \\
\text { KW }\end{array}$ & No & Anderies et al. 2004 \\
\hline $\begin{array}{l}\text { McGinnis, M. D., and E. Ostrom. 2014. Social-ecological system framework: initial } \\
\text { changes and continuing challenges. Ecology and Society 19(2):30. http://dx.doi. } \\
\text { org/10.5751/ES-06387-190230 }\end{array}$ & $\begin{array}{l}\text { Title, Abstr., } \\
\text { KW }\end{array}$ & No & Anderies et al. 2004, Ostrom 2007, 2009 \\
\hline $\begin{array}{l}\text { Green, O. O., A. S. Garmestani, M. E. Hopton, M. T. Heberling. 2014. A multi-scalar } \\
\text { examination of law for sustainable ecosystems. Sustainability 6:3534-3551. }\end{array}$ & Abstr. & No & Ostrom et al. 2007 \\
\hline
\end{tabular}


Berbés-Blàzquez, M., J. S. Oestreicher, F. Mertens, and J. Saint-Charles. 2014 Ecohealth and resilience thinking: a dialog from experiences in research and practice. Ecology and Society 19(2):24. http://dx.doi.org/10.5751/ES-06264-190224

Bergsten, A., D. Galafassi, and Ö. Bodin. 2014. The problem of spatial fit in socialecological systems: detecting mismatches between ecological connectivity and land management in an urban region. Ecology and Society 19(4):6. http://dx.doi. org/10.5751/ES-06931-190406

Fidel, M., A. Kliskey, L. Alessa, and O. P. Sutton. 2014. Walrus harvest locations reflect adaptation: a contribution from a community-based observing network in the Bering Sea. Polar Geography 37(1):48-68. http://dx.doi.

org/10.1080/1088937X.2013.879613

Ratner, B. D., K. Mam, and G. Halpern. 2014. Collaborating for resilience: conflict, collective action, and transformation on Cambodia's Tonle Sap Lake. Ecology and Society 19(3):31. http://dx.doi.org/10.5751/ES-06400-190331

Aarras, N., M. Rönkä, M. Kamppinen, H. Tolvanen, and P. Vihervaara. 2014. Environmental technology and regional sustainability: the role of life-based design. Technology in Society 36:52-59. http://dx.doi.org/10.1016/i.techsoc.2013.12.003 Carey, M., M. Baraer, B. G. Mark, A. French, J. Bury, K. R. Young, and J. M. McKenzie. 2014. Toward hydro-social modeling: merging human variables and the social sciences with climate-glacier runoff models (Santa River, Peru). Journal of Hydrology 518:60-70. http://dx.doi.org/10.1016/j.jhydrol.2013.11.006

Delgado-Serrano, M., E. Oteros-Rozas, P. Vanwildemeersch, C. Ortiz Guerrero, S. London, and R. Escalante. 2015. Local perceptions on social-ecological dynamics in Latin America in three community-based natural resource management systems. Ecology and Society 20(4):24. http://dx.doi.org/10.5751/ES-07965-200424 Edelenbos, J., I. van Meerkerk, and C. van Leeuwen. 2015. Vitality of complex water governance systems: condition and evolution. Journal of Environmental Policy \& Planning 17(2):237-261. http://dx.doi.org/10.1080/1523908X.2014.936584 Hiedanpää, J., and J. Pellikka. 2015. Adapting moose hunting: a case study on fragmented hunting grounds around Nuuksio National Park in Helsinki metropolitan area, Finland. European Journal of Wildlife Research 61:303-312.

Van Vliet, N., J. Fa, and R. Nasi. 2015. Managing hunting under uncertainty: from one-off ecological indicators to resilience approaches in assessing the sustainability of bushmeat hunting. Ecology and Society 20(3):7. http://dx.doi.org/10.5751/ ES-07669-200307

McGreavy, B., L. Lindenfeld, K. Hutchins, L. Silka, J. Leahy, and B. Zoellick. 2015. Communication and sustainability science teams as complex systems. Ecology and Society 20(1):2. http://dx.doi.org/10.5751/ES-06644-200102

Loos, J., A. I. Horcea-Milcu, P. Kirkland, T. Hartel, M. Osváth-Ferencz, and J. Fischer. 2015. Challenges for biodiversity monitoring using citizen science in transitioning social-ecological systems. Journal for Nature Conservation 26:45-48. http://dx.doi.org/10.1016/j.jnc.2015.05.001

Gerlach, G., S. Herpertz, and S. Loeber. 2015. Personality traits and obesity: a systematic review. Obesity Reviews 16:32-63. http://dx.doi.org/10.1111/obr.12235 Xiaojin, W., L. Yanxu, and Y. Xinjun. 2015. A resilience-based analysis on the spatial heterogeneity of vegetation restoration and its affecting factors in the construction of eco-cities: a case study of Shangluo, Shaanxi. Acta Ecologica Sinica 35(13):4377-4389. Vogt, J. M., S. L. Watkins, S. K. Mincey, M. S. Patterson, and B. C. Fischer. 2015. Explaining planted-tree survival and growth in urban neighborhoods: a socialecological approach to studying recently planted trees in Indianapolis. Landscape and Urban Planning 136:130-143. http://dx.doi.org/10.1016/j.landurbplan.2014.11.021 Pinsky, M. L., and D. Byler. 2015. Fishing, fast growth and climate variability increase the risk of collapse. Proceedings of the Royal Society B 282:20151053. http://dx.doi. org/10.1098/rspb.2015.1053

Rommel, J. 2015. What can economic experiments tell us about institutional change in social-ecological systems? Environmental Science \& Policy 53:96-104. http://dx.doi. org/10.1016/j.envsci.2014.05.006

Harcourt, S., V. A. Green, and C. Bowden. 2015. "It's everyone's problem": parents' experiences of bullying. New Zealand Journal of Psychology 44:4-14.

García-Llorente, M., C. M. Rossignoli, F. Di Iacovo, and R. Moruzzo. 2016. Social farming in the promotion of social-ecological sustainability in rural and periurban areas. Sustainability 8:1238.

Mullon, C., F. Steinmetz, G. Merino, J. A. Fernandes, W. W. L. Cheung, M. Butenschön, and M. Barange. 2016. Quantitative pathways for Northeast Atlantic fisheries based on climate, ecological-economic and governance modelling scenarios. Ecological Modelling 320:273-291. http://dx.doi.org/10.1016/j.ecolmodel.2015.09.027 Yu, D. J., H. C. Shin, I. Pérez, J. M. Anderies, and M. A. Janssen. 2016. Learning for resilience-based management: generating hypotheses from a behavioral study. Global Environmental Change 37:69-78.

Moritz, M., S. Laborde, S. C. Phang, M. Ahmadou, M. Durand, A. Fernandez, I. M. Hamilton, S. Kari, B. Mark, P. Scholte, N. Xiao, and R. Ziebe. 2016. Studying the Logone floodplain, Cameroon, as a coupled human and natural system. African Journal of Aquatic Science 41(1):99-108. http://dx.doi org/10.2989/16085914.2016.1143799

\begin{tabular}{|c|c|c|}
\hline Abstr., KW & Yes & Berkes and Folke 1998 \\
\hline Title, Abstr. & No & Undetermined \\
\hline Abstr. & Yes & Berkes et al. 2003 \\
\hline Abstr. & No & Folke et al. 2010 \\
\hline KW & Yes & Berkes et al. 2003 \\
\hline KW & No & Folke 2006 \\
\hline Abstr. & Yes & $\begin{array}{l}\text { Berkes and Folke 1998, Anderies et al. } \\
\text { 2004, Ostrom } 2009\end{array}$ \\
\hline Abstr., KW & No & Berkes and Folke 1998 \\
\hline Abstr., KW & Yes & Berkes et al. 2003 \\
\hline Abstr., KW & Yes & Berkes and Folke 1998 \\
\hline Abstr. & No. & Walker et al. 2004 \\
\hline Title & No & Berkes et al. 2003 \\
\hline Abstr. & No & Undetermined \\
\hline ----- & ----- & Not analyzed. Main text in Chinese. \\
\hline Abstr., KW & Yes & Ostrom 2009 \\
\hline KW & No & Undetermined \\
\hline $\begin{array}{l}\text { Title, KW, } \\
\text { Abstr. }\end{array}$ & Yes & Redman et al. 2004, Ostrom 2009 \\
\hline Abstr. & No & Undetermined \\
\hline Abstr. & Yes & Ostrom 2009 \\
\hline Abstr. & No & Undetermined \\
\hline Abstr. & No & Various references to papers by Folke \\
\hline
\end{tabular}

Berkes et al. 2003, Ostrom 2009 
Yoon, T. K., S. Kim, T. Takano, S. J. Yun, and Y. Son. 2016. Contributing to sustainability education of East Asian university students through a field trip experience: a social-ecological perspective. Sustainability 8(10):1067.

Brunner, S. H., and A. Grêt-Regamey. 2016. Policy strategies to foster the resilience of mountain social-ecological systems under uncertain global change. Environmental Science \& Policy 66:129-139. http://dx.doi.org/10.1016/j.envsci.2016.09.003

Bouamrane, M., M. Spierenburg, A. Agrawal, A. Boureima, M.-C. Cormier-Salem, M. Etienne, C. Le Page, H. Levrel, and R. Mathevet. 2016. Stakeholder engagement and biodiversity conservation challenges in social-ecological systems: some insights from biosphere reserves in western Africa and France. Ecology and Society 21(4):25. https://doi.org/10.5751/ES-08812-210425

Newig, J., D. Schulz, and N. W. Jager. 2016. Disentangling puzzles of spatial scales and participation in environmental governance-the case of governance re-scaling through the European Water Framework Directive. Environmental Management 58:998-1014. https://doi.org/10.1007/s00267-016-0753-8

Bauch, C. T., R. Sigdel, J. Pharaon, and M. Anand. 2016. Early warning signals of regime shifts in coupled human-environment systems. Proceedings of the National Academy of Sciences of the USA 113:14560-14567. http://dx.doi.org/10.1073/ pnas. 1604978113

C. K. Kanyuuru, J. Mburu, and J. Njoka. 2017. Adaptation of institutional arrangements to management of northern rangelands of Kenya. Environment, Development and Sustainability 19:67-82. https://doi.org/10.1007/s10668-015-9718-v Pascual, U., I. Palomo, W. M. Adams, K. M. A. Chan, T. M. Daw, E. Garmendia, E. Gómez-Baggethun, R. S. de Groot, G. M. Mace, B. Martín-López, and J. Phelps. 2017. Off-stage ecosystem service burdens: a blind spot for global sustainability. Environmental Research Letters 12(7). https://doi.org/10.1088/1748-9326/aa7392 Ingalls, M. L., and D. Mansfield. 2017. Resilience at the periphery: insurgency, agency and social-ecological change under armed conflict. Geoforum 84:126-137. https://doi. org/10.1016/i.geoforum.2017.06.012

Bavinck, M., F. Berkes, A. Charles, A. C. E. Dias, N. Doubleday, P. Nayak, and M. Sowman. 2017. The impact of coastal grabbing on community conservation - a global reconnaissance. Maritime Studies 16:8. https://doi.org/10.1186/s40152-017-0062-8

\begin{tabular}{|c|c|c|}
\hline Abstr. & No & Various references to papers by Folke \\
\hline $\begin{array}{l}\text { Abstr., KW, } \\
\text { Title }\end{array}$ & Yes & Janssen et al. 2007 \\
\hline $\begin{array}{l}\text { Abstr., KW, } \\
\text { Title }\end{array}$ & Yes & Berkes and Folke 1998, Ostrom 2009 \\
\hline Abstr. & No & Berkes and Folke 1998 \\
\hline KW & Yes & Berkes and Folke 1998, Berkes et al. 2003 \\
\hline KW & No. & Various references to papers by Folke \\
\hline Abstr. & Yes & Ostrom 2009 \\
\hline KW & No & Carpenter et al. 2001 \\
\hline Abstr., KW & Yes & Berkes et al. 2003 \\
\hline
\end{tabular}

both the designed and self-organizing components of a SES and to study how they interact" (Anderies et al. 2004). Hence, based on this notion they developed a conceptual model of an SES, consisting of four entities and eight linkages (Fig. 3).

The framework developed by Anderies et al. (2004) in turn inspired the development of the Robustness model, which Elinor Ostrom a few years later established with the purpose of challenging "the presumption that scholars can make simple, predictive models of social-ecological systems (SESs) and deduce universal solutions, panaceas, to problems of overuse or destruction of resources" (Ostrom 2007:15181).

What Ostrom argued for (authors' interpretation) was a refinement and restructuring of the SES framework, mainly based on the following three reasons:

- One may more easily identify variables that otherwise are not considered;

- One may improve conditions to compare cases;

- One may develop a shared language, important for communication and wider understanding.

Moving beyond more simple notions to diagnose the problems and potentialities of linked SESs requires a more serious study of complex, multivariable resource management systems. Hence, another purpose of Ostrom's model was to clarify the structure of an SES in order to understand how a particular solution may help or hinder management outcomes.

Throughout her whole career Ostrom affirmed that the preference for simple solutions to complex governance problems was strong, often referring to Hardin's far-fetched conclusions about the difficult to apply to consciously designed systems, i.e., irrigation systems, the key feature of the model was instead to "recognize interactions within SESs that were especially important with regard to robustness, signifying designed resilience used in engineering when disturbances and shocks are known and the system is being built and designed to withstand these known shocks. The logic behind the model was that because resilience is 
vulnerability of the commons. Instead, Ostrom argued for embracing complexity and for developing better diagnostic methods to identify "combinations of variables that affect the incentives and actions of actors under diverse governance systems" (Ostrom 2007:15181). Empirical observations suggest that simple linear and reductionist dynamics give a misleading representation of how social-ecological systems work (Levin et al. 2012).

Fig. 3. Basic feature of a social-ecological system model. The resource (A) is used by resource users (B) and public infrastructure providers (C). Public infrastructure (D) refers to physical capital (i.e., any engineered works such as dikes, irrigation canals, etc.) and social capital (i.e., the rules used by those governing, managing, and using the system including monitoring and enforcement of these rules). In the examination of robustness, external disturbance (Arrow 7) can be addressed (i.e., biophysical disruptions such as floods, earthquakes, landslides, and climate change) as well as socioeconomic changes (Arrow 8), e.g., population increases, economic and major political changes that impact on the resource users (B) and the public infrastructure providers (C). Arrow numbers in the figure signify interaction as follows: (1) between resource and resource users; (2) between users and public infrastructure providers; (3) between infrastructure providers and public infrastructure; (4) between public infrastructure and resource; (5) between public infrastructure and resource dynamics; (6) between resource users and public infrastructure; (7) external forces on resource and infrastructure; (8) external forces on social actors. Source: Anderies et al. 2004.

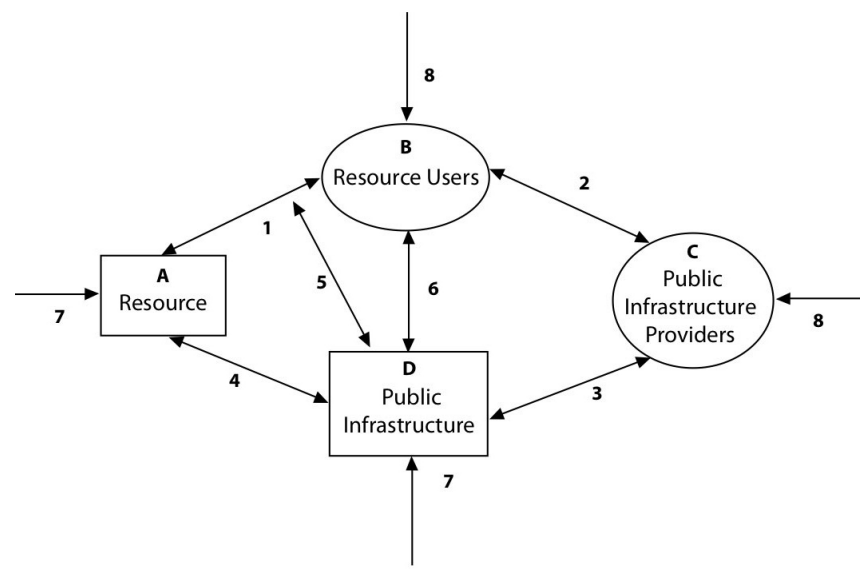

Ostrom also referred to the multitude of variables that over time have been identified by various researchers that affect the patterns of interactions and outcomes in empirically studied SESs, such as the large dataset provided by Agrawal (2001). As a result, she developed a diagnostic method for structuring and organizing these variables, depictured in Figure 4, where these variables can be further structured so that it enables scholars to organize analyses of how attributes of a resource system, its resource units generated, its resource users, and the governance system jointly affect and are indirectly affected by interactions and resulting outcomes achieved at a particular time and place.
The basic idea behind the multitier framework (Fig. 4) is that it enables researchers to organize second-tier variables in a nested fashion, and improve understanding of how these may affect and be affected by the larger socioeconomic, political, and ecological settings in which these variables are embedded. Scholars of sustainability science could then identify variables that either sustain or collapse the resource management systems under study (Ostrom 2007).

In a publication in Science in 2009, Ostrom asserted "that efforts are currently under way to revise and further develop the SES framework with the goal of establishing comparable databases" (Ostrom 2009:422). Unfortunately, she was not given adequate time to realize this ambition.

Fig. 4. A general framework for the highest-tier variables that scholars need to analyze when examining linked socialecological systems. Source: Based on and modified from Ostrom (2007).

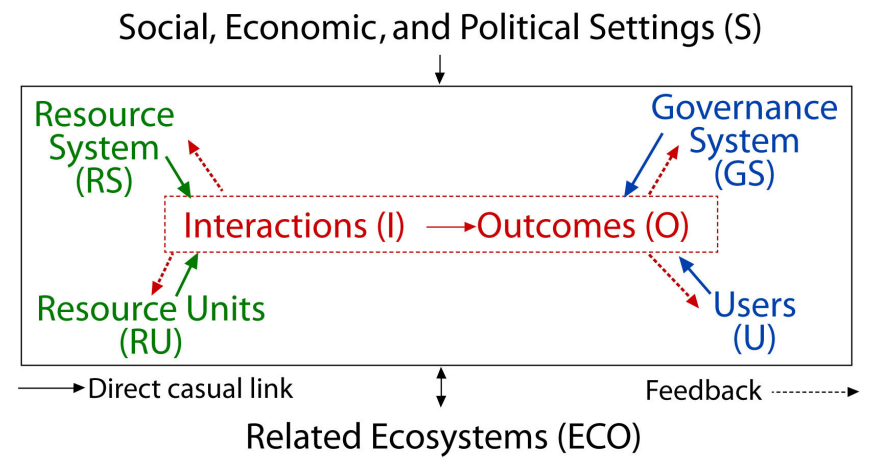

\section{Emergent assessment themes}

What emerges as a concluding finding in our assessment of articles is the lack of a common analytical framework for the analysis of SESs. In a review of SES modeling, Schlüter et al. (2012) arrive at the same conclusion, asserting that the frameworks existing are the ones by Anderies et al. and Ostrom, dealt with in the previous section. However, and as shown in our Scopus review, the original framework developed by Berkes and Folke (1998) appears to be the one that most scholars have been inspired by in their analysis of SES. This descriptive model has also been successfully used in the analysis of other settings than local resource management systems, e.g., in detangling novel insights about informal stewardship management of urban ecosystems and their services (e.g., Colding et al. 2003, Colding 2013, Andersson et al. 2014).

Although the frameworks by Anderies et al. and Ostrom could be regarded as diagnostic frameworks that could be used for further modeling (Schlüter et al. 2012), the framework developed by Berkes and Folke could more adequately be described as a descriptive framework, primarily dealing with the linkages among institutions, management practices, and different environmental knowledge systems.

\section{The lack of a SES definition}

A critical result of our assessment is a lack of a unifying definition of SES in the publications looked into. Altogether, $61 \%$ of the papers did not provide any definition at all of what SES actually 
stands for and how the concept was used. In cases when the concept is defined, authors provide quite a number of different definitions that range from quite trivial ones to more complicated ones. This drawback is probably a consequence of the lack of a more detailed original definition of the concept. With the exception of Anderies et al. (2004), neither Ostrom, nor Berkes and Folke, provide any more precise definition of the concept. For example, Berkes and Folke (1998:4) used this characterization when emphasizing the linkage between social and ecological systems: "We hold the view that social and ecological systems are in fact linked, and that the delineation between social and natural systems is artificial and arbitrary."

Suffice it to say, the lack of a more thorough definition of SES may also be because Berkes and Folke applied a quite narrow view of what a social system consisted of for the purpose of the original SES framework, stating that social systems were those that deal with property rights, land and resource tenure systems, environmental worldviews and ethics, and different types of knowledge systems pertinent to the environments in which they were situated (Berkes and Folke 1998).

Considering that only approximately one-third of the papers analyzed in this review provide a definition of SES, we call for a more unifying definition of the concept. One may, for example, ask what actually is meant by the term social in the SES concept. Does it include economy, technology, and the humanities? This uncertainty, in turn, leaves the door open for scholars to come up with their own homegrown interpretations and definitions of SES, creating an overall confusion of the concept's scientific relevance. Although increased conceptual vagueness of a concept can be valuable to foster communication across disciplines and between science and practice (Brand and Jax 2007), overlapping definitions and confusion about how a concept is used reduces its utility (Anderies et al. 2013). A clearer definition would for sure avoid the "blind elephant analogy" that runs the risk of circumscribing the SES concept (Fig. 5).

Although it may be hard to delineate any type of social system from another, it may be wise, though, as a minimum recommendation to include economics as a vital component in the definition of SES. This has, for example, been done in the paper by Levin et al. (2012). A more thorough definition, we argue, should at least embrace the well-known social-economicecological triad inherent in the notion of sustainable development. Although the lack of a common analytical framework of SES poses significant challenges for the emerging field of SES (Schlüter et al. 2012), a more precise definition is also warranted to avoid the risk of the SES discourse becoming diluted (Marshall 2012).

\section{CONCLUSIONS}

As our review clearly shows there exist basically three major analytical frameworks that scholars commonly adopt and are inspired by when studying interlinked social and ecological systems. These are here referred to as the original, the robustness, and the multitier frameworks. Although the first one can be described as having a descriptive focus, the latter two have a more diagnostic focus, compatible for SES modeling. As the review also shows, the SES discourse is a steadily growing knowledge field. However, over its 20 years' course of existence the SES concept still lacks a more unifying definition. Whereas most scholars may have a pretty good understanding of what a social-ecological system entails, the lack of a more detailed definition is a drawback when communicating it to a broader multidisciplinary audience. As in all scientific explorations a clear definition of the terms and concepts of the scientific endeavor is critical to ensure that scholars speak the same language and that useful comparisons can be made.

Fig. 5. The lack of a common analytical framework of socialecological systems (SES) is a significant challenge for the field of SES to develop and communicate with other social and natural science fields. Artwork by Jonas Adner.

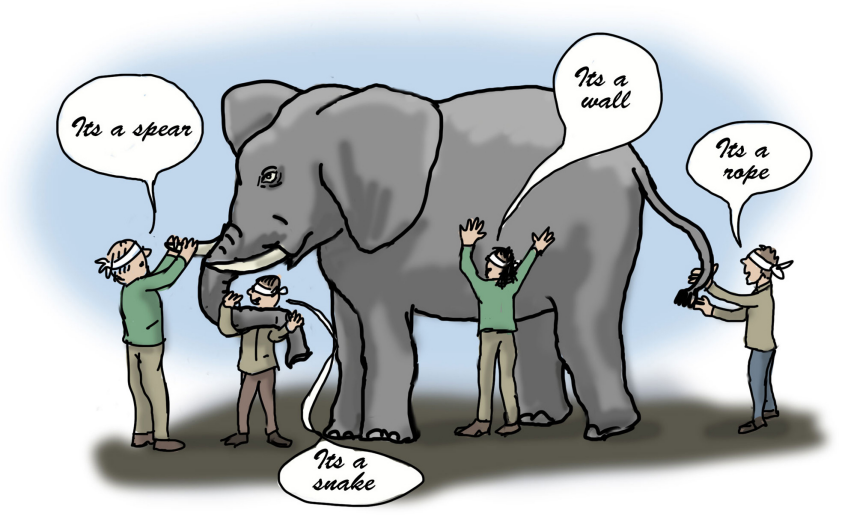

Responses to this article can be read online at: http://www.ecologyandsociety.org/issues/responses. php/10598

\section{Acknowledgments:}

We would like to thank the Beijer Institute of Ecological Economics, and funding secured from MISTRA for the Stockholm Resilience Centre, as well as the Department of Building, Energy and Environmental Engineering at the University of Gävle in supporting this work. Thanks to reviewers and editorial comments for improving the manuscript. Thanks also to Jonas Adner for nice art work of figures and up-grading of graphics.

\section{LITERATURE CITED}

Agrawal, A. 2001. Common property institutions and sustainable governance of resources. World Development 29(10):1649-1672. http://dx.doi.org/10.1016/S0305-750X(01)00063-8

Anderies, J. M., C. Folke, B. Walker, and E. Ostrom. 2013. Aligning key concepts for global change policy: robustness, resilience, and sustainability. Ecology and Society 18(2):8. http:// dx.doi.org/10.5751/ES-05178-180208

Anderies, J. M., M. A. Janssen, and E. Ostrom. 2004. A framework to analyze the robustness of social-ecological systems from an institutional perspective. Ecology and Society 9(1):18. http://dx. doi.org/10.5751/ES-00610-090118 
Andersson, E., S. Barthel, S. Borgström, J. Colding, T. Elmqvist, C. Folke, and $\AA$. Gren. 2014. Reconnecting cities to the biosphere: stewardship of green infrastructure and urban ecosystem services. Ambio 43:445-453. http://dx.doi.org/10.1007/s13280-014-0506-y

Berkes, F. 2017. Environmental governance for the Anthropocene? Social-ecological systems, resilience, and collaborative learning. Sustainability 9:1232. http://dx.doi. org/10.3390/su9071232

Berkes, F., J. Colding, and C. Folke. 2003. Navigating socialecological systems: building resilience for complexity and change. Cambridge University Press, Cambridge, UK. http://dx.doi. org/10.1017/cbo9780511541957

Berkes, F., and C. Folke, editors. 1998. Linking social and ecological systems: management practices and social mechanisms for building resilience. Cambridge University Press, Cambridge, UK.

Biggs, R., M. Schlüter, and M. L. Schoon, editors. 2015. Principles for building resilience: sustaining ecosystem services in socialecological systems. Cambridge University Press, Cambridge, UK. http://dx.doi.org/10.1017/cbo9781316014240

Bouamrane, M., M. Spierenburg, A. Agrawal, A. Boureima, M.C. Cormier-Salem, M. Etienne, C. Le Page, H. Levrel, and R. Mathevet. 2016. Stakeholder engagement and biodiversity conservation challenges in social-ecological systems: some insights from biosphere reserves in western Africa and France. Ecology and Society 21(4):25. https://doi.org/10.5751/ES-08812-210425

Brand, F. S., and K. Jax. 2007. Focusing the meaning(s) of resilience: resilience as a descriptive concept and a boundary object. Ecology and Society 12(1):23. http://dx.doi.org/10.5751/ ES-02029-120123

Carpenter, S. 2008. What is a social-ecological system? Stockholm Resilience Centre, Stockholm University, Sweden.

Carpenter, S., B. Walker, J. M. Anderies, and N. Abel. 2001. From metaphor to measurement: resilience of what to what? Ecosystems 4(8):765-781. http://dx.doi.org/10.1007/s10021-001-0045-9

Cherkasskii, B. L. 1988. The system of the epidemic process. Journal of Hygiene Epidemiology Microbiology and Immunology 32(3):321-328.

Colding, J. 2013. Revisiting the Stockholm Urban Assessment. Pages 313-336 in T. Elmqvist, M. Fragkias, J. Goodness, B. Güneralp, P. J. Marcotullio, R. I. McDonald, S. Parnell, M. Schewenius, M. Sendstad, K. C. Seto, and C. Wilkinson, editors. Urbanization, biodiversity, and ecosystem services: challenges and opportunities. Springer, Dordrecht, The Netherlands.

Colding, J., T. Elmqvist, J. Lundberg, K. Ahrné, E. Andersson, S. Barthel, S. Borgström, A. Duit, H. Erntsson, and M. Tengö. 2003. The Stockholm Urban Assessment (SUA-Sweden). The Millennium Ecosystem Assessment Sub-global summary report. Beijer Discussion Paper Series No. 182. The Beijer Institute of Ecological Economics, Royal Academy of Sciences, Stockholm, Sweden. [online] URL: http://www.beijer.kva.se/PDF/60278360 Disc182. pdf

Colding, J., and C. Folke. 2001. Social taboos: "invisible" systems of local resource management and biodiversity conservation. Ecological Applications 11:584-600. http://dx.doi.org/10.2307/3060911
Delgado-Serrano, M., E. Oteros-Rozas, P. Vanwildemeersch, C. Ortíz Guerrero, S. London, and R. Escalante. 2015. Local perceptions on social-ecological dynamics in Latin America in three community-based natural resource management systems. Ecology and Society 20(4):24. http://dx.doi.org/10.5751/ ES-07965-200424

Fidel, M., A. Kliskey, L. Alessa, O. P. and Sutton. 2014. Walrus harvest locations reflect adaptation: a contribution from a community-based observing network in the Bering Sea. Polar Geography 37(1):48-68. http://dx.doi.org/10.1080/1088937X.2013.879613

Folke, C. 2006. Resilience: the emergence of a perspective for social-ecological systems analyses. Global Environmental Change 16:253-267. http://dx.doi.org/10.1016/j.gloenvcha.2006.04.002

Folke, C., and F. Berkes. 1998. Understanding dynamics of ecosystem-institution linkages for building resilience. Beijer Discussion Paper No. 112. The Beijer Institute of Ecological Economics, Royal Academy of Sciences, Stockholm, Sweden.

Folke, C., S. R. Carpenter, B. Walker, M. Scheffer, T. Chapin, and J. Rockström. 2010. Resilience thinking: integrating resilience, adaptability and transformability. Ecology and Society 15(4):20. http://dx.doi.org/10.5751/ES-03610-150420

Harrington, R., C. Anton, T. P. Dawson, F. de Bello, C. K. Feld, J. R. Haslett, T. Kluvánkova-Oravská, A. Kontogianni, S. Lavorel, G. W. Luck, M. D. A. Rounsevell, M. J. Samways, J. Settele, M. Skourtos, J. H. Spangenberg, M. Vandewalle, M. Zobel, and P. A. Harrison. 2010. Ecosystem services and biodiversity conservation: concepts and a glossary. Biodiversity and Conservation 19(10):2773-2790. http://dx.doi.org/10.1007/ s10531-010-9834-9

Holling, C. S., and L. H. Gunderson. 2002. Resilience and adaptive cycles. Pages 25-62 in L. H. Gunderson and C. S. Holling, editors. Panarchy: understanding the transformations in human and natural systems. Island, Washington D.C., USA.

Janssen, M. A., J. M. Anderies, and E. Ostrom. 2007. Robustness of social-ecological systems to spatial and temporal variability. Society \& Natural Resources 20:307-322. http://dx.doi. org/10.1080/08941920601161320

Janssen, M. A., and E. Ostrom. 2006. Governing social-ecological systems. Pages 1465-1509 in L. Tesfatsion and K. L. Judd, editors. Handbook of computational economics, Vol 2. Elsevier, Amsterdam, The Netherlands.

Keesing, R. M. 1981. Cultural anthropology. A contemporary perspective. Second edition. Hartcourt Brace Jovanovich College Publishers, New York, New York, USA.

Levin, S., T. Xepapadeas, A.-S. Crépin, J. Norberg, A. de Zeeuw, C. Folke, T. Hughes, K. Arrow, S. Barrett, G. Daily, P. Ehrlich, N. Kautsky, K.-G. Mäler, S. Polasky, M. Troell, J. R. Vincent, and B. Walker. 2012. Social-ecological systems as complex adaptive systems: modeling and policy implications? Environment and Development Economics 18:111-132. http://dx.doi.org/10.1017/ $\underline{\mathrm{S} 1355770 \mathrm{X} 12000460}$

Marshall, S. 2012. Science, pseudo-science and urban design. Urban Design International 17:257-271. http://dx.doi.org/10.1057/ udi. 2012.22 
Ostrom, E. 1990. Governing the commons: the evolution of institutions for collective action. Cambridge University Press, New York, New York, USA. http://dx.doi.org/10.1017/CBO9780511807763

Ostrom, E. 2007. A diagnostic approach for going beyond panaceas. Proceedings of the National Academy of Sciences 104 (39):15181-15187. http://dx.doi.org/10.1073/pnas.0702288104

Ostrom, E. 2009. A general framework for analyzing sustainability of social-ecological systems. Science 325 (5939):419-422. http://dx.doi.org/10.1126/science.1172133

Ostrom, E. 2010. Beyond markets and states: polycentric governance of complex economic systems. American Economic Review 100:641-672. http://dx.doi.org/10.1257/aer.100.3.641

Ostrom, E., M. A. Janssen, and J. M. Anderies. 2007. Going beyond panaceas. Proceedings of the National Academy of Sciences 104:15176-15178. http://dx.doi.org/10.1073/pnas.0701886104

Özerol, G. 2013. Institutions of farmer participation and environmental sustainability: a multi-level analysis from irrigation management in Harran Plain, Turkey. International Journal of the Commons 7(1):73-91. http://dx.doi.org/10.18352/ ijc. 368

Ratzlaff, E. D. 1970. Applications of engineering systems. Analysis to the human social-ecological system. Thesis. Department of Mechanical Engineering, University of California, Davis, USA.

Redman, C. L., J. M. Grove, and L. H. Kuby. 2004. Integrating social science into the long-term ecological research (LTER) network: social dimensions of ecological change and ecological dimensions of social change. Ecosystems 7(2):161-171. http://dx. doi.org/10.1007/s10021-003-0215-Z

Schlüter, M., R. R. J. McAllister, R. Arlinghaus, N. Bunnefeld, K. Eisenack, F. Hölker, E. J. Milner-Gulland, B. Müller, E. Nicholson, M. Quaas, and M. Stöven. 2012. New horizons for managing the environment: a review of coupled social-ecological systems modeling. Natural Resource Modeling 25(1):219-272. http://dx.doi.org/10.1111/j.1939-7445.2011.00108.x

Thomas, C. R., I. J. Gordon, S. Wooldridge, and P. Marshall. 2012. Balancing the tradeoffs between ecological and economic risks for the Great Barrier Reef: a pragmatic conceptual framework. Human and Ecological Risk Assessment 18(1):69-91. http://dx.doi.org/10.1080/10807039.2012.631470

Walker, B. H., J. M. Anderies, A. P. Kinzig, and P. Ryan. 2006. Exploring resilience in social-ecological systems through comparative studies and theory development: introduction to the special issue. Ecology and Society 11(1):12. http://dx.doi. org/10.5751/ES-01573-110112

Walker, B., C. S. Holling, S. R. Carpenter, and A. Kinzig. 2004. Resilience, adaptability and transformability in social-ecological systems. Ecology and Society 9(2):5. http://dx.doi.org/10.5751/ ES-00650-090205 